\title{
Utilisation of Educational Media in Teaching and Learning of History and Government in Selected Secondary Schools in Kenya
}

\author{
Eunice Rugut ${ }^{1}$ and Lazarus Ndiku Makewa $(\mathrm{PhD})^{2}$ \\ ${ }^{1}$ TSC Nandi County, Kenya \\ ${ }^{2}$ Solusi University, Zimbabwe \\ P.O. Box 760-30300, Kapsabet Kenya, East Africa
}

\begin{abstract}
The study investigated the utilisation of educational media and its effect on teaching and learning process in secondary schools in Nandi Central Sub-County. The study was conducted in 10 secondary schools in Nandi Central Sub-County, 5 of which were low performing schools while 5 were high performing schools. The response rate for the study comprised of 26 History and Government teachers and 180 Form Four students. A causal comparative research design approach was utilised. The students were selected through cluster sampling techniques (high and low performing) while teachers were selected through stratified random sampling technique. Questionnaires for students and teachers formed the main instrument for data collection. The data analysis utilised both descriptive and inferential statistics. The results of the study showed that educational media resources are rarely used by teachers in teaching of History and Government in secondary schools in Nandi Central Sub-County. The utilisation of educational media was higher in high performing schools as compared to low performing ones. Majority of teachers relied on reference books, school work books, magazines and newspapers in teaching the subject as opposed to adoption of technological innovations like computers, projectors and internet in teaching the subject. The results of the study showed that inadequate provision of educational media resources coupled with inadequate support for the integration of the new media resources in teaching and learning were challenges that influenced utilisation of educational media in teaching and learning.
\end{abstract}

Key words: Educational Media, High performing schools, History and Government, Low performing schools

\section{INTRODUCTION}

Following an international meeting of experts held in 1982 in Grunwald in Germany; United Nations Education Scientific and Cultural Organisation (UNESCO) published a declaration making the argument for media education (UNESCO, 2001). The Grunwald Declaration argues that the media are an increasingly significant and powerful force in contemporary societies; and that a coherent and systematic form of education about the mass media must be seen as an essential component - indeed, a prerequisite of modern citizenship. Advocates of media education have often argued that it should be seen as an element of all curriculum subjects. There are several reasons for this argument, that there is the fact that all teachers use media of different kinds as "teaching aids" - not only audio-visual media, but also textbooks and other print materials. For example, History teachers will routinely use films or photographs as sources of evidence alongside printed documents (UNESCO, 2006).

The Kenya Institute of Education (KIE) (2002) recommends the use of the following instructional media in teaching and learning in secondary schools; (i) Print media which refers to textbooks, newspapers, journals, magazines and practical(ii) Non projected media, which refers to the materials that use a combination of drawing words, pictures and other symbols e.g. chalkboards, maps and magnetic boards. (iii) Silent projected media which refer to materials that are projected but have no sound e.g. slide, film strips, and microfilms. (iv) Audio-media which refers to sound materials such as audio-tape, recordings or radios. (v) Audio-visual media which refers to materials that utilise sight and sound like filmstrips, documentaries and videotapes (vi) Recommended also the usage of internet to acquire up to date information (KIE, 2002).

KIE (2002) reinforces the need for History and Government teacher need to be conversant with different instructional media used in schools. This is because as Joyce and Weil (1980) said that no model of teaching is designed to accomplish all types of learning or to work for all learning styles. This means that no single method of teaching is the best for all situations and with all teachers and students. Kochhar (1991) added that the method the teacher adopts should emerge out of the abundance of information and skill of the teacher. In another scenario, researchers have suggested that rich, authentic contexts that can be facilitated by multimedia environments encourage students to become engaged with the content, explore more deeply, and develop more 
complex views of issues...tools and resources available in multimedia learning environments may be used to help scaffold more disciplined inquiry into ill-structured problems (Brush \& Saye, 2005). Kenya National Examination Council (KNEC, 2016) indicated that there had been an increase in History and Government performance nationally over the past three years for high performing schools in Nandi Central Sub County with a mean of 6.9 points as opposed to low performing schools who had a mean of 4.75 points for the past five years. This shows that disparity exists between high and low performing secondary schools within the study area and it is not known whether utilisation of educational media in teaching and learning the subject could be the cause for this.

Various studies have been conducted in Kenya and beyond on utilisation of educational media resource in teaching and learning in Kenya secondary schools. However, a closer look shows that none has been done on utilisation of educational media in teaching and learning History and Government subject in secondary schools within Nandi Central Sub-County. For example, Ngetich and Ndege (2011) studied on the utilisation of instructional methods in teaching conflict resolution methods in Social Studies in primary schools within Kosirai Division, Nandi North Sub-County, they established that most teachers had not attended in - service training on emerging issues in the subject. From this background information, it is clear that there is inadequate research to determine how educational media resources have impacted on improved performance in Nandi Central History and Government subject in the past three five years (2011-2015).

\section{PURPOSE OF THE STUDY}

The study sought to investigate teachers and students perceptions on the utilisation of educational media and its effect in teaching and learning History and Government in selected secondary schools in Nandi Central Sub-County, Kenya.

\section{Research Questions:}

The study sought to answer the following research questions:

1. To what extent are educational media utilized in teaching and learning History and Government in secondary school within Nandi Central Sub-County?

2. Is there a significant difference in the utilisation of educational media in teaching and learning History in high and low performing secondary schools in Nandi Central Sub-County?

\section{LITERATURE REVIEW CONCEPT OF EDUCATIONAL MEDIA}

In its definition of media education, the Grunwald Declaration (1982) which was held in Germany reflects several key emphases that continue to be shared by the majority of media educators today: media education is concerned with the full range of media, including moving image media (film, television, video), radio and recorded music, print media (particularly newspapers and magazines), and the new digital communication technologies. It aims to develop a broad-based 'literacy', not just in relation to print, but also in the symbolic systems of images and sounds (UNESCO, 2001).Media education is concerned with teaching and learning about the media. This should not be confused with teaching through the media - for example, the use of television or computers as a means of teaching science, or history. Media education is not about the instrumental use of media as 'teaching aids': it should not be confused with educational media (Buckingham, 2001).Media education aims to develop both critical understanding and active participation. It enables young people to interpret and make informed judgments as consumers of media; but it also enables them to become producers of media in their own right, and thereby to become more powerful participants in society (UNESCO, 2006). Media education is about developing young people's critical and creative abilities (KIE, 2002). Over the past twenty years, several interrelated changes - some of them foreseen in the Grunwald declaration itself have made the argument for media education even more urgent (UNESCO, 2001). Media has increasingly penetrated all areas of social life: it is now impossible to understand the operations of the political process or of the economy, or to address questions about cultural and personal identity - or indeed about education - without taking account of the role of media.

Educational media has the potential to transform the process of teaching and learning. Educational media are defined as modes of delivery systems or teaching and learning methods employed in an educational process with the view of facilitating the attainment of the set goals or objectives. Ngetich and Ndege (2011) indicates that some of the educational used in teaching History and Government include; lecture, class discussion, problem solving, role playing, group work, question and answer, use of resource persons, storytelling, field trips, debates, and essay writing. The teacher chooses the instructional method to be used when teaching different topics.

\section{EDUCATIONAL MEDIA RESOURCES}


Ayot (1984) classified media resources into three categories namely, audio materials, visual materials and audio-visual materials

Audio materials - Audio materials are those whose contents are received through the sense of hearing. Examples of these are radio, records tapes as illustrated in Table 2.

Table 1 Kinds of educational media

\begin{tabular}{|c|c|c|}
\hline No. & Education Media & Specifications \\
\hline i) & Printed materials & $\begin{array}{ll}\text { A. } & \text { Supplementary Books } \\
\text { (i) } & \text { Workbooks } \\
\text { (ii) } & \text { Duplicated outlines } \\
\text { (iii) } & \text { Teacher-study guides } \\
\text { (iv) } & \text { Reference Books } \\
\text { (v) } & \text { Magazines and articles } \\
\text { (vi) } & \text { News papers } \\
\end{array}$ \\
\hline ii) & Audio Resources & $\begin{array}{ll}\text { 1. } & \text { Radio } \\
\text { 2. } & \text { Photograph } \\
\text { 3. } & \text { Tape recorders }\end{array}$ \\
\hline iii) & Visual resources & $\begin{array}{l}\text { (A) Chalkboard } \\
\text { (B) Still pictures } \\
\text { (i) Non projected } \\
\text { Photographs } \\
\text { Illustrations } \\
\text { (ii) Projected pictures } \\
\text { Slides } \\
\text { Film strips } \\
\text { Overhead projectors } \\
\text { (c) Graphic materials } \\
\text { i) Charts } \\
\text { ii) Graphs } \\
\text { iii) Maps and globes } \\
\text { iv) Posters } \\
\text { (D) Exhibits } \\
\text { (i) School-made displays } \\
\text { (ii) Bulletin boards } \\
\text { (iii) Museums } \\
\text { (E) Objects } \\
\text { (i) Realias } \\
\text { (ii) Models }\end{array}$ \\
\hline Iv & Audiovisual resources & $\begin{array}{ll}\text { (i) } & \text { Motion pictures } \\
\text { (ii) } & \text { Television } \\
\text { (iii) } & \text { Video tapes } \\
\text { (iv) } & \text { Computer }\end{array}$ \\
\hline
\end{tabular}

Radio- is an important resource through which teachers can capture broadcasted programs from radio stations and use them directly in the instruction process. Simkins, Cole, Telavin and Means (2002) maintain that a simple telephone call to a radio station programming department can provide information about upcoming programs so that teachers can plan ahead of time of the listening or taping

(i) Phonographs.

(ii) Tape recorders

Visual Materials are those that involve the sense of sight in the learning process. They are also known as the "non-projected" media. The examples of these are maps, charts, pictures, photographs, chalkboards, realia, models, simulation materials and field trips among (Lardizabel, et al., 1991). According to Mayer (2005), people can learn more deeply from words and pictures than from words alone. He also argues that multimedia learning occurs when people build mental representations from words) printed text) and pictures (such as illustrations, photos, animations or video. The visual instructional resources include the following:

Library - is a special building or room in which teachers and learners can locate books, magazines and news papers, maps and many other instructional resources which can be used in the teaching and learning process. 
Simkins, et al., (2002) advised that a subject teacher needs to ensure the availability of textbooks and supplementary books when students need them in the library.

Pamphlet and Handouts are used principally to reduce the amount of time students spend copying notes or diagrams from aboard or screen. They can be used in a variety of ways directly related to the lesson content, for example a power point generated handout of a slide presentation and a practical guide to using a particular resource like a data base guide on as a permanent source of reference (Smart College, 2012).

Pictures and photographs are powerful means through which story telling method can be used in the instructional process. A teacher can use sequence pictures, single pictures and photographs in introducing and telling stories (Pirozzi 1995).

Newspapers- a teacher can assign some responsibility for students to skim different newspapers from which they can extract valuable information which can be applicable in the instructional process (Simkins, et al., 2002).

Chalkboard is one of the most important visual materials that a teacher needs in the instructional process. Although modern technology is threatening the use of chalkboard, a number of researches have proved it's usability in the teaching and learning process. More than $70 \%$ of faculties at the University of California, for instance, preferred traditional chalkboard over white magnetic make board (Smart College, 2012).

Audio-visual materials - Television and video are sources of information through which the visual and audio components are combined to facilitate learning. Wetzel, Radtle and Stern (1994) argue that motion is a unique beneficial feature of video or film instruction because of the attention value when it directly represents information that is difficult to describe verbally. Through television, a teacher can assign groups of students to monitor information channel and give report in the classroom (Simkins, et al., 2002). Galbi (2001) argued that television could be used to supplement reading and other classroom activities effective use of teaching aids (retrieved on 12 December 2012) has stipulated that video tapes add a dimension and therefore helps students to visualize

Internet/Online search - Internet can provide access to a growing variety of resources. As search engines become more sophisticated, it is easier for the teacher to find relevant sites for a given topic and extract information that can be utilized during the instructional process (Mayer, 2005).

\section{AVAILABILITY AND USE OF EDUCATIONAL MEDIA IN CLASSROOMS}

According to Adefuye (2006), the presence of the various learning resources in schools, such as audiovisual aids, arouses students' interest towards learning and definitely might have positive effects on performance. Audio-visual aids takes the forms of technological devices, amongst these are: tape recorders, radio broadcasts, public address system, overhead and opaque projectors. As teaching resources, they are useful for the presentation and clarification of information. Furthermore, the need for adequate supply of books especially textbooks in schools libraries in terms of quality can be of immense importance towards the academic development or performance of the students (Neo, 2007).

From finding of Mitchell and Miranda and Russell (2011) and Web and Cox (2004), "good learning requires constant variation in the purposeful intellectual activities of the learner and a wide range of pedagogical stratifies". To them many teachers do not have access to didactic materials and modern educational technologies (laboratory, printer, video, multimedia, software etc), which could have made training learner - centred. Researches had been conducted on learning environment in different countries like USA, Australia, Netherlands, Nigeria etc. such researches include the research reported by Wang (2008) who did a study in secondary classroom environments, comparing learning environments in different types of schools (good, average and below) and different educational streams and established that there existed significant different on the utilisation of educational media among different categories of schools. There was also a study on secondary science laboratory environments using the SLEI $(\mathrm{Neo}, 2007)$ that assessed the learning environment form the perceptions of students and teachers. Students perceived that they were interested in being taught by their teachers in laboratories as opposed to their classrooms while teachers said that students are active when different methodologies are employed during teaching and learning process.

Adeyemo (2011) asserts that the interest in the study of learning environment has become more prominent since it has been evident that learning outcomes and students' attitude towards learning were closely linked to the learning environment. Classroom learning environment refers to a setting or space where teachers and learners interact with each other, use variety of tools and information resources with each other, and use variety of tools and information resources in their pursuit of learning activities (Young, 2006). The nature of classroom environment and psycho-social interaction can make a difference in how the students' learning and achieve their goals (Lingerfelter \& Lingerfelter, 2003).

Availability of media resources in secondary school is of great concern to teachers, school administration and curriculum developers. Many writers and researchers have discussed the concept of 
availability of teaching and learning resources. Tucker (1986) holds that because media are created as integral elements of the curriculum, there is an obligation to ensure that all learners have access to the materials, if resources are considered inevitable to the learning then they should be at hand in all the schools. Education department of Tuckman (1999) holds that establishing an environment for effective English speaking and listening requires learners to be exposed to real life situation and facilities that place increasingly complex demand on the way language is used.

Clements (2000) indicates that computers in the classroom contribute to cognitive development. He further explains the different ways in which computers can be introduced in a classroom, which correspond with research conducted by Simkins et al., (2002), Bruce and Levin (1997) in Taft (2000) on the application or uses of computers in the classroom. Geisert and Futrel (2000) observe that the use of Information and Communication Technology (ICT) for assessment facilitate teaching. According to Geisert and Futrel (2000), data analysis techniques have potential of tracking learners' achievements and review teaching strategies according to insight gained.

\section{MATERIALS AND METHODS}

This study was designed as a causal comparative. Neumann (2007) indicates that causal comparative research attempts to determine reasons or causes for the existing condition. The study was carried out in Nandi Central Sub County, Nandi County. The Sub-County has two divisions; Kapsabet and Kilibwoni. The study selected 10 secondary schools; 5 high performing and 5 low performing who have been registering for History and Government subject for KCSE in the past three years. The sample for the study comprised of: 43 History and Government teachers and 257 Form Four students. Three research instruments were developed by the researcher to be used for the study. The instruments used were questionnaires and document checklists. The data analysis procedure included two main phases, the descriptive statistical data analysis and the qualitative data analysis. Descriptive statistics; frequencies, percentages, means and standard deviation were used to analyse data on the availability and use of educational media resource in teaching and learning History and Government. Independent t-test was used to calculate the differences in the utilisation of educational media in the teaching and learning of History in high and low performing secondary schools in Nandi Central SubCounty. The significant level was based at 0.05 .

\section{RESULTS}

\section{Extent to which educational media utilized in teaching and learning History and Government}

This is the first research question that sought teachers and student perception towards the extent to which educational media was being utilised in teaching and learning of History and Government in secondary schools. At first the study sought to find out students evaluation of the degree to which their History and Government teachers utilised various educational media in teaching and learning the subject in classrooms based on the scale;

$$
\begin{array}{ll}
1-1.49 \text { Never } & \\
1.5-2.49 & \text { Rarely } \\
2.5-3.49 & \text { Sometimes } \\
3.5-4.49 & \text { Often } \\
4.5-5 \quad \text { Always } &
\end{array}
$$

Table 2 Students' evaluation of educational media use in teaching and learning history and government

\begin{tabular}{|l|c|c|c|}
\hline Extent of media utilisation & $\mathbf{N}$ & Mean & $\begin{array}{c}\text { Std. } \\
\text { Deviation }\end{array}$ \\
\hline $\begin{array}{l}\text { We use a variety of reference books in learning } \\
\text { History }\end{array}$ & 180 & 3.7444 & 1.24228 \\
\hline $\begin{array}{l}\text { We utilize school work books to complete our } \\
\text { assignments }\end{array}$ & 179 & 3.7151 & 1.35013 \\
\hline $\begin{array}{l}\text { My teachers encourage us to read magazines to learn } \\
\text { History }\end{array}$ & 3.0559 & 1.38499 \\
\hline $\begin{array}{l}\text { Our History teacher use educational tools and } \\
\text { information resources to increase productivity, } \\
\text { promote creativity and facilitate academic learning }\end{array}$ & 179 & 2.9441 & 1.51665 \\
\hline $\begin{array}{l}\text { My teacher evaluates and selects new information } \\
\text { resources and technological innovations based on their } \\
\text { appropriateness to specific tasks }\end{array}$ & 180 & 2.7833 & 1.45807 \\
\hline $\begin{array}{l}\text { My teacher requires to make charts to illustrate the } \\
\text { migration and trading routes }\end{array}$ & 180 & 2.7333 & 1.50456 \\
\hline
\end{tabular}




\begin{tabular}{|l|c|c|c|}
\hline $\begin{array}{l}\text { My teacher uses educational media to locate, evaluate, } \\
\text { and collects information from a variety of sources }\end{array}$ & 2.7056 & 1.40111 \\
\hline $\begin{array}{l}\text { In class, we discuss current issues from the } \\
\text { newspapers on governance issues }\end{array}$ & 180 & 2.5833 & 1.31546 \\
\hline $\begin{array}{l}\text { My History teacher discusses diversity issues } \\
\text { presented in radio and television programmes in } \\
\text { teaching of History }\end{array}$ & 280 & 2.4500 & 1.34237 \\
\hline $\begin{array}{l}\text { My History teacher use photographs and pictures to } \\
\text { explain past history }\end{array}$ & 180 & 2.3111 & 1.44659 \\
\hline $\begin{array}{l}\text { My teacher assigns us to make posters on cultural } \\
\text { practices of different communities }\end{array}$ & 180 & 2.0500 & 1.27842 \\
\hline $\begin{array}{l}\text { My teacher requires us to listen to relevant Radio } \\
\text { Programmes and provide questions for us to answer }\end{array}$ & 180 & 1.8611 & 1.06631 \\
\hline $\begin{array}{l}\text { We listen to recorded tapes on the biographies past } \\
\text { leaders }\end{array}$ & 179 & 1.5754 & .92933 \\
\hline $\begin{array}{l}\text { My teacher uses projectors in teaching History and } \\
\text { Government subject }\end{array}$ & 180 & 1.5278 & .92411 \\
\hline $\begin{array}{l}\text { My teacher uses video tapes in enriching History and } \\
\text { Government learning. }\end{array}$ & 180 & 1.4778 & .86816 \\
\hline We use internet to answer History assignments & 180 & 1.4611 & .95346 \\
\hline $\begin{array}{l}\text { We use computers to locate and collect information on } \\
\text { History }\end{array}$ & 180 & 1.4556 & .84114 \\
\hline Valid N (Listwise) & $\mathbf{1 7 6}$ & $\mathbf{2 . 3 7 8 2}$ & $\mathbf{. 5 7 9 9 6}$ \\
\hline Use of Educational Media & & $5014)$ \\
\hline
\end{tabular}

Descriptive statistics shows History teachers use reference books $(\mathrm{M}=3.74$ and $\mathrm{SD}=1.24)$ and school workbooks $(\mathrm{M}=3.7$ and $\mathrm{SD}=1.35)$ more often in learning History and Government subject in secondary schools in the Sub-County. This shows that teachers prefer using print media educational resources in teaching very often as compared to current and electronic ones. The students results show that teachers often encourage us to read magazines to learn History $(\mathrm{M}=3.05$ and $\mathrm{SD}=1.38)$ and the teachers often used educational tools and information resources to increase productivity, promote creativity and facilitate academic learning. However, students indicated that their teacher rarely $(\mathrm{M}=2.4$ and $\mathrm{SD}=1.34)$ discussed diversity issues presented in radio and television programmes in teaching of History, photography and pictures in explaining past history $(\mathrm{M}=2.3$ and $\mathrm{SD}=1.4)$, make posters on cultural practices on different communities $(\mathrm{M}=2.1$ and $\mathrm{SD}=1.2)$ and they rarely used various radio programmes and provide questions for answers $(\mathrm{M}=1.86$ and $\mathrm{SD}=1.0)$. Moreover, the study findings showed that students never listened to recorded tapes on the biographies of past leaders $(\mathrm{M}=1.57$ and $\mathrm{SD}=0.9)$, projectors $(\mathrm{M}=1.52$ and $\mathrm{SD}=0.92)$, video tapes $(\mathrm{M}=1.47$ and $\mathrm{SD}=0.86)$, internet $(\mathrm{M}=1.4$ and $\mathrm{SD}=0.95)$ and computers in locating and collecting information on history $(\mathrm{M}=1.4$ and $\mathrm{SD}=0.84)$. These results are inconsistent with Clements (2000) survey that showed that secondary schools had provided computers, contributed to cognitive development of learners. On average, student responses on the study findings shows that the use of educational media is rare $(\mathrm{M}=2.37$ and $\mathrm{SD}=0.57)$.

Teachers seem to use print media in teaching the subject as opposed to electronic media like internet, projectors or tape recorders. This significantly affect classroom environment as the latter method is more teacher centered rather than being subject centered or learner centered. This could describe the slight improvement in History and Government performance in secondary schools. The scenario is different from American schools whereby all public schools are connected with internet and are provided with appropriate infrastructure facilities to facilitate learning (Miranda and Russell, 2011). The same has happened in Thailand where all classrooms across the nation have become connected and publishers are now offering various instructional books and teaching supplements to secondary schools (Lavin, Korte, and Davies, 2010). The non use of current educational media in teaching and learning History and Government in Nandi Central SubCounty secondary schools could be due to non - availability of these resources in majority of secondary schools coupled with lack of electricity infrastructure in their schools.

Teachers' Evaluation on the Extent of educational media utilization in teaching and learning History and Government

The study also sought to find out teachers evaluation on the extent to which educational media are utilized in teaching and learning History and Government in secondary schools in Nandi Central Sub-County. Through a scale of five;

$$
\begin{array}{ll}
1-1.49 \text { Never } & \\
1.5-2.49 & \text { Rarely }
\end{array}
$$




$\begin{array}{ll}2.5-3.49 & \text { Sometimes } \\ 3.5-4.49 & \text { Often } \\ 4.5-5 & \text { Always }\end{array}$

The findings are given in Table 3.

Table 3 Teachers' Evaluation on the extent of educational media utilization in teaching History and Government

\begin{tabular}{|c|c|c|c|}
\hline Extent of use of educational media & $\mathbf{N}$ & Mean & Std. Deviation \\
\hline I use a variety of reference books in Teaching History. & 26 & 4.3077 & .78838 \\
\hline I utilize school work book to instruct my students. & 26 & 3.5769 & .94543 \\
\hline I encourage students to read magazines to learn History. & 26 & 3.4231 & 1.02657 \\
\hline $\begin{array}{l}\text { In class, we discuss current issues from the newspapers } \\
\text { on governance issues. }\end{array}$ & 26 & 3.3846 & .98293 \\
\hline $\begin{array}{l}\text { I use educational tools and information resources to } \\
\text { increase productivity, promote creativity and facilitate } \\
\text { academic learning. }\end{array}$ & 26 & 3.2692 & 1.21845 \\
\hline $\begin{array}{l}\text { I discuss diversity issues presented in radio and } \\
\text { television programmes in teaching of History. }\end{array}$ & 26 & 3.1923 & .98058 \\
\hline $\begin{array}{l}\text { I evaluate and select new information resources and } \\
\text { technological innovations based on their appropriateness } \\
\text { to specific tasks }\end{array}$ & 26 & 3.0385 & 1.03849 \\
\hline I use photographs and pictures to explain past history. & 26 & 2.9231 & 1.01678 \\
\hline $\begin{array}{l}\text { I use educational media to locate, evaluate, and collect } \\
\text { information from a variety of sources }\end{array}$ & 26 & 2.8846 & 1.14287 \\
\hline $\begin{array}{l}\text { I require my students to make charts to illustrate the } \\
\text { migration and trading routes }\end{array}$ & 26 & 2.7692 & .95111 \\
\hline $\begin{array}{l}\text { I use computers to locate and collect information on } \\
\text { History. }\end{array}$ & 26 & 2.5769 & 1.60432 \\
\hline $\begin{array}{l}\text { I assign my students to listen to relevant Radio } \\
\text { Programmes and I provide questions for them to answer. }\end{array}$ & 26 & 2.3846 & 1.02282 \\
\hline $\begin{array}{l}\text { I assign my students to make posters on cultural } \\
\text { practices of different communities }\end{array}$ & 26 & 2.2308 & .95111 \\
\hline $\begin{array}{l}\text { I provide time for my History students to listen to } \\
\text { recorded tapes about the biographies of past leaders. }\end{array}$ & 26 & 1.9231 & .84489 \\
\hline $\begin{array}{l}\text { I use video tapes in enriching History and Government } \\
\text { learning. }\end{array}$ & 26 & 1.4615 & .70602 \\
\hline My students use internet to answer History assignments. & 26 & 1.4231 & .57779 \\
\hline $\begin{array}{l}\text { I use projectors in teaching History and Government } \\
\text { subject. }\end{array}$ & 26 & 1.3077 & 67937 \\
\hline Valid N (Listwise) & 26 & & \\
\hline Use Of Educational Media & 26 & 2.7104 & .51252 \\
\hline
\end{tabular}

The teachers also seem to agree that they often use variety of reference books in teaching History and Government $(\mathrm{M}=4.3$ and $\mathrm{SD}=0.78)$ and utilize school work book to instruct their students $(\mathrm{M}=3.57$ and $\mathrm{SD}=0.94)$. This corroborates with students responses who also indicated that their teachers use reference books and workbooks in teaching and learning the subject in secondary schools. The checklists also showed that 7 schools had adequate reference and workbooks for learning while only 3 had the instruments but they were inadequate. The teachers also said that they often encourage students to read magazines to learn History ( $M=3.4$ and $\mathrm{SD}=1.02$ ), they discussed often current issues from newspapers on governance issues $(\mathrm{M}=3.38$ and $\mathrm{SD}=0.98)$, they also often use educational tools and information resources to increase productivity $(\mathrm{M}=3.26$ and $\mathrm{SD}=1.21$ ) and they also often discussed issues presented in presented in mass media in teaching the subject $(\mathrm{M}=3.19$ and $\mathrm{SD}=0.98)$.

Moreover, teachers indicated that they rarely used computer to locate and collect information on History and Government $(\mathrm{M}=2.57$ and $\mathrm{SD}=1.6)$, they rarely assigned students to listen to various radio programmes $(\mathrm{M}=2.38$ and $\mathrm{SD}=1.02)$, making of posters on cultural practices of different communities $(\mathrm{M}=2.2$ and $\mathrm{SD}=0.95)$ and listening of recorded tapes about biographies of past leaders $(\mathrm{M}=1.92$ and $\mathrm{SD}=0.84)$. In addition, the teachers also agreed with the respondents that they never used video tapes $(\mathrm{M}=1.46$ and $\mathrm{SD}=0.70)$, internet $(\mathrm{M}=1.42$ and $\mathrm{SD}=0.57)$ and use of projectors $(\mathrm{M}=1.3$ and $\mathrm{SD}=0.67)$. This implies that electronic media 
technology is not applied in majority of secondary schools within the Sub-County. The result agrees with students' results on how the instructional resources are utilized in teaching and learning the subject in secondary schools. The results are different from Fabos and Young (1999)

Study in Wisconsin state secondary schools whereby teachers had negative perception towards the utilisation not because the of cost, unavailability and inappropriateness but psychological components in teachers perception towards the integration of the media in teaching and learning process in schools. This shows that the adoption and use of various educational media (especially the current ones) is dependent on the psychological reasons that a teacher may hold towards its use.

Existence of significant difference in the utilisation of educational media in teaching and learning History in high and low performing secondary schools in Nandi Central Sub-County

The second research question for the study sought to find out if there existed significant difference on the utilisation of educational media in teaching and learning history and Government between low and high performing schools in the study area. An independent sample $\mathrm{t}$ - test was computed and the groups result statistics are summarised in Table 4.

Table 4 Test of difference between low and high performing

\begin{tabular}{|l|l|c|c|c|c|}
\hline & School performance & N & Mean & $\begin{array}{c}\text { Std. } \\
\text { Deviation }\end{array}$ & $\begin{array}{c}\text { Std. Error } \\
\text { Mean }\end{array}$ \\
\hline $\begin{array}{l}\text { Use of educational } \\
\text { media }\end{array}$ & High-performing & 100 & 2.3553 & .57236 & .05724 \\
\cline { 2 - 6 } & Low-performing & 80 & 2.4068 & .59170 & .06615 \\
\hline
\end{tabular}

Descriptive statistics results shows that on the use of educational media in teaching and learning History and government, there were slight differences between low $(\mathrm{M}=2.4$ and $\mathrm{SD}=0.59)$ and high $(\mathrm{M}=2.35$ and $\mathrm{SD}=0.57)$ performing secondary schools. This shows that students from both schools agreed that educational media are rarely used in teaching and learning History and Government in secondary schools in the Sub-County.

Table 5 Independent Samples T-Test

\begin{tabular}{|l|l|c|c|c|c|c|c|c|}
\hline \multicolumn{2}{|l}{} & $\begin{array}{l}\text { Levene's Test } \\
\text { for Equality } \\
\text { of Variances }\end{array}$ & \multicolumn{6}{|c|}{ t-test for Equality of Means } \\
\cline { 2 - 8 } & F & Sig. & T & df & $\begin{array}{c}\text { Sig. } \\
(\mathbf{2 -} \\
\text { tailed) }\end{array}$ & $\begin{array}{c}\text { Mean } \\
\text { Difference }\end{array}$ & $\begin{array}{c}\text { Std. Error } \\
\text { Difference }\end{array}$ \\
\hline $\begin{array}{l}\text { Use of educational } \\
\text { media }\end{array}$ & $\begin{array}{l}\text { Equal } \\
\text { variances } \\
\text { assumed }\end{array}$ & .085 & .771 & - & 178 & .555 & -.05152 & .08715 \\
\hline
\end{tabular}

The null hypothesis stated that:

Ho1 There is no significant difference between high and low performing schools in the use of educational media in teaching and learning History and Government

Based on the statistics, the null hypothesis is accepted that there exist no significant difference between high and low performing schools use of educational media resources since the calculated $\mathrm{p}-$ value was greater than 0.05 ( $p>0.05)$. This shows that both students from low and high perfuming schools share common opinion on the rarity of use of educational media in teaching and learning History and Government in secondary schools in the Sub-County. The result of the study is different from Wang (2008) who established that there existed significant difference $(\mathrm{p}<0.05)$ between good, average and below performing categories of schools.

\section{CONCLUSIONS AND RECOMMENDATIONS}

On the basis of the results of this study, the researcher was able to reach the following conclusions on the utilization of educational media in secondary schools. With exception of current educational media resources (projectors, computers, internet band width, tape recorders, video tapes models, and Realias) all the selected media resources were available in Nandi Central Sub County secondary schools. Average results showed that only 3 schools had adequate educational media, four also had the resources but they were inadequate while 4 were found to have no several educational media resources in teaching and learning History and Government in secondary schools. Teachers were found to be using print media (textbooks, workbooks, newspapers, charts and maps) most as opposed to radios, televisions, tape recorders and internet. The reason for 
this was due to the fact that most schools within the area did not have ICT laboratories while some teachers acknowledged that they did not have skills and knowledge in using current educational media like projectors, computers and I - pads. On the basis of the findings and conclusions of this study, the researcher recommends that:

1. Schools under investigations should increase the number of teachers, photographs, maps, charts, computers, movies and films, newspapers, magazines and internet so as to ensure that schools match the current instructional methods that improve students understanding of the subject.

2. Teachers should increase the use of available television, bulletin boards and computers, which are readily available in some schools but rarely in the instructional process.

3. Teachers should guide students to create educational media e.g. charts, drawings and pictures. This will increase the availability of educational media for teaching and learning.

4. The Kenya Institute for Curriculum and Development (KICD formerly KIE) should change the curriculum to incorporate the use of new educational media resources in History and Government teaching

[1] Adefuye, M. (2006). Teacher's Awareness and Extent of Utilisation of Information Communication Technologies for Effective Science and Health Education in Nigeria. Singapore Journal of Scientific Research, 5, 26-58.

[2] Adeyemo, S.A (2011). The Effect of Teachers' Perception and Students' Perception of Physics Classroom Learning Environment on their Academic Achievement in Senior Secondary Schools Physics. International Journal of Educational Research and Technology, 2 (1), 74 - 81.

[3] Ayot, H.O. (1984). Language for learning: A methodology book for English language learning in secondary schools. Nairobi: Macmillan.

[4] Brush, T. A. \& Saye, J. W. (2004).The effects of multimedia-supported problem-based inquiry on student engagement, empathy, and assumptions about history. Journal of Educational Multimedia and Hypermedia, 8(4), 43-56.

[5] Brush, T. A. \& Saye, J. W. (2005).Scaffolding Critical Reasoning in History and Social Studies: Tools to Support Problem-Based Historical Inquiry. Presented at the annual meeting of the American Educational Research Association, San Francisco.

[6] Buckingham, D. (2001). Media Education: A Global Strategy for Development. A Policy Paper Prepared for UNESCO Sector of Communication and Information.

[7] Clements, D. H. (2000). From exercises and tasks to problems and projects: Unique contributions of computers to innovate Mathematics education. The journal of mathematical behaviour, 19(1), 9-47.

[8] Galbi, D.A. (2001). Communication Policy, Media Development and convergence Retrieved march 10 , 2009 from http://www.galbituink.org/media2.html

[9] Geisert, P. G \& Futrel, M. K. (1995). Teachers, Computers and Curriculum: Microcomputers in the classroom. N. J: Prentice Hall.

[10] Joyce, K \& Weil, M. (1980). Models of teaching. New Jersey: Prentice-Hall, Inc.

[11] Kenya Institute of Education (2002). Revised Secondary School Syllabus. Nairobi: KIE.

[12] Kochhar, S.K. (1991). The teaching of Social Studies. New Delhi: Sterling Publishers Private Ltd.

[13] Lardizabel, A.S. Buston A.S., Bucu, L.C., \& Tangaco, M.G (1991).Principles and methods of teaching. Quezon City: Phoenix Publishing House, Inc.

[14] Lingerfelter, J.E. \& Lingerfelter, S.G. (2003).Teaching Cross Culturally: An international model for learning and Teaching. Michigan Baker Academic.

[15] Mayer, R.E. (2005). Cambridge hand book of multimedia learning. USA: Cambridge University Press.

[16] Miranda, H., \& Russell, M. (2011). Predictors of teacher-directed student use of technology in elementary classrooms: A multilevel SEM approach using data from the USEIT study. Journal of Research on Technology in Education, 43(4), 301-323. Retrieved from EBSCO host.

[17] Neo, M. (2007). Learning with multimedia: engaging students in constructivist learning. International Journal of Instructional Media, 34(2), 149-158.

[18] Neumann, L. (2007). Research Methods: Qualitative and Quantitative Approaches. Oakland: Sage Publication.

[19] Ngetich, T.H. \& Ndege, P. (2011).Instructional Methods Used in Teaching Conflict Resolution in Social Studies in Primary Schools. Paper Presented at Kabarak $1^{\text {st }}$ International Conference.

[20] Pirozzi, R. (1995). Strategies for reading and study skills.USA: NTC Publishing Company.

[21] Smart College (2012).Guidelines for smart college classroom. homepage retrieved on 12/02/2012 from http:www.classroom.com.

[22] Taft, C. (2000). A Rational for Integrating technology into the classroom. Available: at http://middle.usm.k12-k12.wi.us/faculty/taft/technology/report.html [2004, February 12]. 
[23] Tucker, R .N. (1986).The Integration of Media into the Curriculum. London: Billing and Sons Ltd, Worcester.

[24] Tuckman, B.W. (1999). Conducting educational research. Australia: Wadsworth.

[25] UNESCO (2001).Teacher education through distance learning. Technology, curriculum, evaluation and cost. Paris. Higher Education Division, UNESCO.

[26] UNESCO (2006).Media Education: A Kit for Teachers, Students, Parents and Professionals. Paris: UNESCO

[27] Wang, Q. A (2008). A generic model for guiding the integration of ICT into teaching and learning. Innovations of Education and Teaching International, 45, (4), 411- 419

[28] Webb, M., \& Cox, M. (2004). A review of pedagogy related to information and communications technology. Technology, Pedagogy and Education, 13 (3), 235-286.

[29] Wetzel, C.D, Radtle, P.H \& Stern, H.W (1994).Instructional Effectiveness of Video Media. New Jersey. Lawrence Erlbaum Associates Publishers.

[30] Young. S.S.C.J KU, H. (2006) .A study of innovative uses of ICT in primary education in Mizoguch. R., Dillenbourg , P \& SHU, S. (2006). Learning by effective utilisation of technologies. Facilitating intercultural understanding. Amsterdam: 15 press. 